\title{
The Production of Toolboxes and Hand Tools in Industrial Craft Apprenticeship
}

This article considers the educational and social significance of specific types of 'foreigner' production in twentieth century industrial craft apprenticeship. A 'foreigner' is a regionallyspecific term referring to a practice whereby workers customarily produce personal objects at work, without formal authorization, but with the tacit support of tradespeople and supervisors. Foreigner-making is a global phenomenon also known as homers, government jobs, foreign orders and la perruque. The example considered here is the practice of handmaking toolboxes and customized tools during an engineering patternmaking apprenticeship, in the context of twentieth century Australian manufacturing. This article finds that this type of 'semilegitimate' foreigner production contributed to a process of apprentice enskillment, and held particular social significance in the moral economy of industrial workplaces. With this context in mind, the recent business trend towards standardization and factory uniformity can be seen to have negative consequences for craftworkers. More broadly, the article demonstrates the significance of seemingly 'unproductive' craft practices in the industrial workplace.

Keywords: industrial craft, apprenticeship, homers, toolbox, hand tools, engineering patternmaking 


\title{
The Production of Toolboxes and Hand Tools in Industrial Craft Apprenticeship
}

\begin{abstract}
You know, the fire started in Dean's Marsh, the wind took it to Lorne, a change of wind took it straight up the coast, to Airey's Inlet ... Within half an hour the fire was in Airey's Inlet. So we really had no time. Inadequate water facilities, no sprinklers, only a small 1500 gallon tank of water. The town water supply was just a tiny dribble, so there's no way of fighting or impeding that fire ... I had a chance to chuck my toolbox on somebody's car, get that out, and then the family spent the rest of the night in the water, down at the beach closest, up to our necks, luckily it was low tide and a calm sea, and we had our T-shirts pulled up over our heads because the embers were all dropping around us, and the noise was fearful. Lots of explosions. You know it was just a huge roar. ... So there was my wife and our two children, and I think they had a cat with them, the cat survived as well. ${ }^{1}$
\end{abstract}

These are the recollections of Bryan Poynton, a woodwork artisan and former engineering patternmaker. Poynton and his family survived the Ash Wednesday bushfires, a 1983 disaster which claimed 75 lives in the Australian states of Victoria and South Australia. During the bushfires, Poynton lost his house in Airey's Inlet, his workshop, and most of his tools and works in progress. As he emphasized in his interview, however, what was most important survived: his family. And, as the above quote shows: so did Poynton's toolbox. What was it about this toolbox that made it so precious - precious enough to evacuate it during a lifethreatening bushfire? Poynton made his toolbox during his patternmaking apprenticeship at the International Harvester Company in the Victorian town of Geelong, in the mid-1950s. The custom of allowing woodwork-related apprentices to make their own timber toolboxes was widespread in Australia (among other places) throughout the twentieth century, but has declined in the past two decades.

[Insert Figure 1 near here - Poynton's toolbox]

This article investigates the social and educational significance industrial workplace practices that resulted in objects being crafted 'on the side' by apprentices. More specifically, the focus here is on engineering patternmakers, who, during and after their apprenticeships, designed and crafted timber toolboxes and bespoke tools. Drawing primarily on oral history, I trace how these objects were often produced discretely, during work time, using workplace 
materials and scrap. While such practices were never a mandated requirement of the Australian apprenticeship system, their production was nonetheless widespread and formed part of the cultural reproduction of industrial craft identity. In this way, this article is also about the importance of quietly crafting supposedly 'unproductive' objects at work. It demonstrates how, for apprentices, this formed a vital pedagogical process of 'learning by doing', and was an unofficial staged marker of apprentice achievement.

At the crux of this matter is the issue of how the timber toolbox came into being. By the end of their apprenticeship, twentieth century patternmaking apprentices were expected to have a complete set of their own hand tools, and a handmade toolbox in which to hold them. But, other than a very small 'tool allowance' as part of their pay, apprentices received no other formal support to meet these workplace expectations. Rather, it was craft custom that helped them with this workplace requirement. It was customary, in an apprentice's first year, for an apprentice's 'master' (or the shop 'Foreman') to give them the task of building their own timber toolbox, and allow you at least some work time in which to make it. Some shops provided standardized drawings from which to work off, while others suggested apprentices examine and take dimensions from other patternmakers' toolboxes. ${ }^{2}$

While the task of making this toolbox was not part of the official production of the company or patternshop, this act of making things 'on the side' was quietly tolerated, and viewed as an opportunity for skills development. For individual patternmakers, their handmade toolboxes and the tools they contained - later became important symbolic vectors for patternmakers' personal, collective and professional identities. ${ }^{3}$ The valences attached to these boxes shifted in the late twentieth and early twenty-first centuries, when Australian patternmakers faced two key threats: a declining manufacturing sector (a feature of many wealthy capitalist economies 
at this stage), and the increasing uptake of digital fabrication technologies which usurped patternmakers' manual control of craft.

The following sections provide a brief introduction to engineering patternmaking and introduce the specific Australian manufacturing and apprenticeship context. The article then acknowledges the oral history sources drawn upon in this research, as well as outlining existing studies of making 'on the side'. From there, the article shifts to the empirical material, featuring the experiences of patternmakers in their apprentice years. Finally, I consider what has happened to these clandestine creative practices in the contemporary context: drawing on a case of the roll-out of ' $5 \mathrm{~S}$ ' standardization in the foundry sector, I reveal how business management methods can have unforeseen and significant impacts for apprentice training and for the material culture of the shopfloor.

\section{Engineering Patternmaking in Context}

Engineering patternmaking is necessary for a variety of metal and plastics manufacturing processes that involve molding and casting. ${ }^{4}$ Since the trade emerged as a discrete craft specialization in the nineteenth century (in association with the growth of metal casting), patternmakers have maintained reputations as high-precision woodworkers with substantial engineering knowledge. A patternmaker's work involves closely following engineering or design drawings, in order to plan and produce patterns, jigs, models, molds and core-boxes: all three-dimensional forms that transform a designer's or an engineer's idea into a moldable form, suitable for production.

While patternmaking has not been given a great deal attention in existing craft analysis, there are notable exceptions. Glenn Adamson has called for more attention to patternmaking, as one 
of a number of "understudied but vital" examples of industrial craft. ${ }^{5}$ And Sarah Fayen Scarlett has explored how the patternmaker and furniture designer Charles Rohlfs went to great lengths to hide his industrial connections, lest it sully his reputation as an Arts \& Crafts artisan. ${ }^{6}$ As Scarlett notes, patternmaking is a clear example of the interconnectivity - rather than the divide - between craft and mass-production. ${ }^{7}$ As a trade, patternmaking is poorly understood both because of its complexity, but also because it occurs in the intermediate stages of product development: after the design stage, but before the final product comes into being. Patternmakers' hands do not touch the final commodity. The fruits of their labor patterns - are handcrafted 'one-offs'. Patternmakers' work is thus invisible to most of us, and patterns themselves usually discarded or destroyed once production ceases. A patternmaker's work is consequently rather ego-less. Perhaps, then, it should come as no surprise that patternmakers have chosen to use their extensive practical skills to design and make things other than patterns.

Since the late twentieth century, patternmakers' tasks have been transformed - and arguably deskilled - by the increasing uptake of digital fabrication technologies. ${ }^{8}$ This includes the increasing use of Computer Aided Drafting software (CAD), Computer Numerically Controlled (CNC) milling machines, and more recently, improved methods of 3D printing. These technologies effectively reduce patternmakers' labor to machine set-up and handfinishing computer-generated patterns. This has made the patternmaking trade less attractive as a source of satisfying work, and contributes to the widespread perception that the trade no longer exists, as the following section will unpack.

\section{Engineering Patternmaking in Australia}


In the Australian apprenticeship system (largely inherited from the United Kingdom), patternmaking apprentices are - like most other trades - indentured to an employer for four years (formerly five).${ }^{9}$ During their apprenticeship they must also attend classes at an approved training facility (previously known as 'technical colleges' or 'trade school', now 'TAFE' - essentially public educational institutions for formalizing trade skills). Patternmaking employers are either small-business patternshops or larger industrial organizations such as foundries. In the nineteenth and twentieth centuries it was common to have a patternshop included within a shipbuilding or a railway works, for instance. Small patternshops tended to have a fluctuating number of skilled workers and are generally nonunionized, while patternshops attached to larger foundries tended to have a stronger union presence. Government-run organizations have historically had a reputation for providing craftspeople with more time to make objects on the side, while private companies operate at a more harried pace (with slow periods). Despite these distinctions between patternshops, a shared culture of making extra objects prevailed across the board.

Histories of apprenticeship can be problematic because, while they effectively served to pass on craft skill, they also involved child abuse, patriarchal masculine rituals and vastly uneven power dynamics. ${ }^{10}$ As noted by labor historian John Shields, even in the mid-twentieth century Australian apprenticeship agreements "echoed the paternalistic language and class inequities of $19^{\text {th }}$ century 'master and servant' law". ${ }^{11}$ It is, however, important to acknowledge that industrial craft apprenticeships also became powerful sources of identity and achievement, and they structured nearly everything in an apprentice's life that followed, both positive and negative, with echoes that continue to be felt in the contemporary context. Apprenticeship situated a person's class position, and in some cases limited their future career prospects, but it also accorded their hands - and their minds - with their own particular 
material 'super-power'. This was certainly the case for engineering patternmakers, who continue to deeply value their (now rare) capacity to materialize delicate, precise forms.

In the contemporary context, patternmaking in Australia (as with other locations) is now considered a 'rare trade', a skillset on the verge of disappearance. ${ }^{12}$ This is partly due to the technological shifts, but economic factors have also had a significant influence on the decline of the trade. As with other Western capitalist economies, Australian manufacturing has suffered from a combination of 'economic rationalist' and neoliberal policy since the 1980s, which had the effect of diminishing local manufacturing in favor of industries such as mineral extraction and the service and financial sectors. Australian trades training has also suffered from funding cuts in trades training institutions, negatively impacting apprenticeship uptake. I will return to the issue of contemporary apprentice training further on.

\section{Oral Histories}

This research draws on ethnographic and oral history research conducted between 2015 to 2019, in foundries, patternshops and private homes in the Australian states of New South Wales, Queensland and Victoria. It combines material from two separate research projects: foundry fieldwork in 2015, ${ }^{13}$ and an oral history project I led between 2017 and 2019 Reshaping Australian Manufacturing. ${ }^{14}$ The interviews feature engineering patternmakers, patternmaking business owners and patternmaking trade educators. Two women and ten men were formally interviewed, with ages ranging from their early 30 s to late 80 s. The project thus represents several generations of industrial craft experience. In addition to the formally recorded interviews, the research process also included social media observation of a Patternmakers' Facebook Group, phone calls with patternmakers and industry commentators, visits to patternshops and foundries, taking photographs, and the analysis of apprentice 
training manuals. ${ }^{15}$ Of the $30+$ patternmakers I interviewed and spoke to informally, only two had not made their own toolbox, and all had spent at least some of their time at work making things on the side.

Much has been said over the past four decades about the purpose and complexity of using oral history in historical research. Oral history interviews should be understood not as an attempt to 'tap in' to some direct source of experiential truth, but as a co-production of meaning, where insights into values, social practice and collective narrative can be drawn out. ${ }^{16}$ In attempting to understand a workplace practice that was unofficial and sometimes secretive, official sources can at times be limited, and anecdotal and object-based sources offer opportunities. Craft theorist Ezra Shales has argued that there is value in visiting workshops and speaking with industrial craft practitioners about what they do, particularly because it provides first-hand experience of materials and tools in action. As Shales notes, oral histories add an individualized and human element to what could otherwise result in generalizations. ${ }^{17}$ In my experience of conducting lengthy 'whole of life' interviews, the interviewees' experiences of patternmaking are given much deeper contextualization when they are understood as part of a person's familial, social, educational and geographical context. ${ }^{18}$

Although the medium is aural, oral history interviews can be a very material, object-oriented exercise. Before, during and after the interview, physical objects are regularly presented to me; treated by the interviewees almost as 'evidence'. I was regularly presented with prized antique chisels, revered sharpening stones in purpose-designed boxes, well-thumbed technical manuals, photographs, small timber patterns, and finely turned woodwork articles. I was often invited to visit the patternmaker's home-workshop (most patternmakers had one, if they had 
the space). Here, we found carefully organized stockpiles of rare timber, customized handmade workbenches, sculptural works in progress, extensive supplies of hand tools and woodwork machinery, and, almost without fail, a timber toolbox made during their apprenticeship. While the toolbox was rarely the focus of extended discussion, it tended to linger in the periphery of our conversations. As we have seen from Poynton's quote at the beginning of this article, the toolbox was often referenced in passing. Sometimes it was even present physically, in the corner of the room, gestured to occasionally, bearing witness.

Initially, it must be said, I took these toolboxes for granted. It is already established in histories of craft that handmade boxes are made by amateur and professional woodworkers. ${ }^{19}$ Existing studies have examined the specific and evolving meanings of craft tools for their makers. ${ }^{20}$ After the first few interviews, however, some nagging questions about the toolboxes arose. I quickly ascertained that the patternmaker's toolbox was typically made in the first year of their apprenticeship, when the apprentice was usually only 16 years old. ${ }^{21}$ What, I wondered, was the formal status of this toolbox, vis-à-vis the production output of the patternshop or foundry? Was the toolbox - and the tools contained therein - owned by the apprentice? Or by their employer? Was it produced in-house, during work time, or at home, in the apprentice's personal time? Presumably the production of the toolbox helped patternmaking apprentices develop their precise woodworking skills - but how important was this task to the apprenticeship process?

The patternmakers soon set me straight, all essentially concurring with this explanation: toolboxes and bespoke tools were produced during work time, using workplace materials and recovered scrap wood. While such practices were never a mandated requirement of the Australian apprenticeship system, they were nonetheless widespread, and tacitly condoned in 
the workplace as part of the social reproduction of industrial craft identity. The toolboxes were ultimately the apprentice's property, and they were treasured. As objects, these boxes were seen to express and contain key aspects of the patternmaker's life history and achievement. Nowadays, these boxes exist as objects of pride, but also a profound sense of sadness: representative as they are of a trade that is no longer accorded the recognition it once was.

In attempting to understand the nature of these unofficial craft practices at work, formal sources tend to give little away, while oral history and object-based sources offer opportunities. The introduction of objects into the interview also provided the patternmakers with another way of speaking: lending meaning where they could not always find the words. There are, however, challenges to dealing with objects and photographs during interviews: the conversation does not always adequately provide the words to describe the visuality, physicality and designed nature of what is being discussed. Later on, resultant recording and transcript can feel half-formed, or be misleading. ${ }^{22}$ Given these issues, I took the time to ask tradespeople to describe the objects they were referring to, and explain what those things meant to them personally. Inevitably, the process suited some speakers more than others. When possible, I documented the objects we discussed through photographs. Beyond the recorded interview, I regularly contacted interviewees with follow-up questions, a process that is ongoing. In this way, the observations in this article should be seen as a provisional, opening-up of conversation with industrial craftspeople, not as a final or definitive statement of knowledge about apprentice experience or toolbox production.

\section{Making Things on the Side: Existing Studies of 'Foreigners'}


The covert workplace practice of making objects on the side - in work time, using work materials and space - is a global practice, known by a variety of colloquial names. In the United States they are sometimes called homers. ${ }^{23}$ French theorist Michel de Certeau famously brought the practice to light using the term la perruque. ${ }^{24}$ In places colonized by Britain, the terms government job, private job and fiddling have been used. ${ }^{25}$ Sociologist Michel Anteby - who has studied the practice extensively - noted that the terms pinailles, bousilles and bricoles were used in factories, and he uses the terms side productions and poaching. ${ }^{26}$ In Australia the most common twentieth century labels for making things on the side are foreign orders, foreignies and foreigners. ${ }^{27}$ The precise derivation of the term is unclear, however it points to an undercurrent of racism in twentieth century Australian society - suggesting something from 'outside' that is not-quite proper, on the fringe, and not quite accepted. On the other hand, 'foreigners' were also celebrated, albeit discreetly, by the workers who made them, so the term does not always need to be seen as having negative connotations. Disclaimers aside, 'foreigner' is simply the term most commonly used by the patternmakers I spoke with.

Over the past two decades, a small number of sociological and historical studies have examined how foreigner-making is a workplace practice performed by individuals or groups of workers, to produce objects that are not part of the commercial output of a factory or workshop. ${ }^{28}$ It has been established that foreigner production is a prevalent but seldom publicly acknowledged practice; part of industrial workplace culture and folklore across industrialized economies. ${ }^{29}$ In making foreigners, workers use workplace machinery, scraps or new materials, and factory time, to quietly produce objects. This practice is not often discussed with outsiders, but it occurs with the quiet support of fellow workers, and sometimes supervisors. ${ }^{30}$ Former boilermaker and academic Stephen Smith (distinct from 
patternmaker Stephen Smith in Fig. 2), identifies four categories of foreigner: 1. "a semilegitimate foreigner as indicator of knowledge and skill"; 2) personal objects for home or friends; 3) a "network foreigner" to establish relations with particular workers or groups; or 4) a "commercial foreigner" intended for money or barter (the latter category was uncommon). ${ }^{31}$ The objects made include gifts for departing workers, furniture, toys and household knick-knacks, useful tools and contraptions for the workplace - and boxes.

The practice of making foreigners has been traced to English feudal customs of the Commons. ${ }^{32}$ Prior to the eighteenth-century English Enclosure Acts, the taking of perquisites or 'vails' was understood as a customary right accessible to laborers and servants on feudal lands. ${ }^{33}$ This included taking food, wood, scraps and wastage. The enclosure of the Commons effectively reclassified these practices as theft of private property, thereby producing a criminal underclass. ${ }^{34}$ The definitional line between theft and customary perquisites was ever-changing in the eighteenth and nineteenth centuries, and this ambiguity has echoes in more recent workplace practices. ${ }^{35}$ This social history perspective provides important context, because, as Anteby has noted, foreigner production does not easily fit into established narratives relating to industrial relations, nor business history. ${ }^{36}$ Similarly, we are in the early days of understanding the significance of these practices to histories of craft and design. Existing research into foreigner production has examined its important place in the moral economy of the factory, its importance for workplace culture, and its value as a subtle form of political resistance prompted by the threat of deindustrialization. ${ }^{37}$ Less has been said, however, about the educational role of foreigner-making specifically within craft apprenticeship, nor on how deindustrialization and standardization principles may have potentially eradicated these practices and mentorship experiences, as discussed at the end of this article. 
Patternmakers are an intriguing case for studying foreigners. Their skills in precise woodwork, and their knowledge of metalwork, plastics, fiberglass and resins (among other materials) make patternmakers highly capable makers with the capacity to produce complex and dimensionally accurate shapes. This led to patternmakers' reputation, in some quarters, as the worst (or best) offenders in terms of foreigner production. ${ }^{38}$ Labor historian Bobbie Oliver quoted an oral history interview with patternmaker Patrick Gayton, "if they ever closed the patternshop then we would re-open it ... and call it 'Foreigners Incorporated", 39 The patternshop was often the foreigner-making hub of an industrial establishment, despite official workplace rules that explicitly forbade the activity. ${ }^{40}$

\section{Making one's Toolbox: An Apprenticeship Exercise}

Returning to my initial object of inquiry - the patternmaker's toolbox - it is possible to understand the patternmaker's toolbox as one of the most common foreigners produced in patternshops. Using Smith's aforementioned categories, the timber toolbox would have been a "semi-legitimate" foreigner, produced with the approval and assistance of the tradespeople in charge of an apprentice. It was widely understood that toolboxes made a contribution to the training and development of skilled industrial craftspeople, as well as positively enhancing collective workplace cultures. Such a practice had added practical benefits: providing the apprentice with necessary hand-tools and somewhere to store them. Smith notes that such foreigners "acted as an indicator of individual skill and craft, by which the tradesman, sub-foreman and foreman could measure your progress and development of knowledge". ${ }^{41}$ While the toolbox functioned as a staged marker of skill, it was also intended as the property of the individual apprentice, not the patternshop's. It was thus an 'unproductive' workplace activity, in a strict economic sense. 
As community heritage advocate Ric McCracken identified, twentieth century industrial workplaces had rules such as this:

An employee shall not convert to his own use any material or article the property of the Department, however small its value; and, under no circumstances, may an employee make any tool, pattern, model or article of any description ... for private purposes. ${ }^{42}$

Notwithstanding official rules, it is clear that the production of private articles in work time was widespread in Australian industry. Opening the issue up further (through the example of the Western Australian Government's Midland Railway Workshops), Oliver made a distinction between production by apprentices and by qualified tradespeople:

\footnotetext{
Apprentices were required to make their own tools as part of their training, and they then kept these as their tools of trade, so opportunities doubtless existed for making 'extra' items. Rules 53 and 55 were the most specifically aimed at combating foreigner production, however. The former prohibited employees from ordering 'work of any description' without the authority of the foreman, and the latter stated that employees must not convert to their own use 'any material or article'. ${ }^{43}$
}

In this way, it is clear that apprentices were not subject to the same restrictive rules as fully employed tradespeople, however my anecdotal experience talking to patternmakers suggests that foreigner making did not markedly change when one completed their apprenticeship. Some patternmakers were frequent makers of foreigners: like Bryan Poynton - "they used to call me Homer" - while patternmaker Bruce Phipps described himself as a "good boy", implying he didn't make many foreigners. ${ }^{44}$

\section{[Insert Figure 2 near here - Stephen Smith's toolbox]}

As noted by woodworker and author Jim Tolpin, there are stylistic and functional differences between toolboxes made within different trades. According to Tolpin, the machinists' and patternmakers' toolbox tended to feature drawers that open to the outside, and a frame-andpanel construction, and were smaller than cabinetmakers' toolboxes. ${ }^{45}$ Although Tolpin refers to North American examples, the Australian and New Zealand toolboxes I encountered are similar. [See for example Fig. 2] They took a variety of forms, but most commonly featured 
dovetail joints, and a series of shallow sliding drawers, sometimes concealed behind a removable vertical face panel. Tolpin notes that “there doesn't seem to be any hard evidence that there existed ... any formal rite of passage concerning the building of tool chests". ${ }^{46}$ The key terms of interest here are "hard evidence" and "formal". While such practices were customary and widespread, at least in Commonwealth nations, very little was formally written down in apprenticeship guidelines. ${ }^{47}$

There is one intriguing parallel case in recent literature. Craft theorist Marilyn Zapf's study of twentieth century British engineering craftspeople devotes time to discussing the toolmaker's toolbox. ${ }^{48}$ Some of Zapf's interviewees described having timber toolboxes presented to them as gifts at the end of their apprenticeship, in an unofficial but customary acknowledgement of craft mastery. Zapf understands that these toolboxes were loaded with symbolic significance:

On the shopfloor, these wooden toolboxes serve as an acknowledged reminder of the toolmaker's skill. Therefore, they are a symbol of professionalization, a marker of socially accepted boundaries set around the idea of skill, and arguably the toolmaker's perceived status within the company. Because of their visual distinction and conceptual implications, the toolboxes, and the skills they represent, are a source of pride. $^{49}$

Why did toolmaker apprentices not make their own toolboxes, why were they given them?

While Zapf does not answer this, the answer may prove to be materially specific: toolmakers worked with metal, while patternmakers traditionally worked with timber. A timber toolbox was highly preferable to a metal one, in order to protect the metal tools therein, and avoid instruments becoming blunt and damaged. It therefore makes sense to expect patternmaker apprentices to craft their own toolboxes, and considerably less sense to expect a toolmaking apprentice to undertake the same task. One can readily imagine that, through a tit-for-tat foreigner agreement across an industrial establishment, patternmakers might be called upon to make a toolmaker's toolbox as a foreigner gift. 
Returning to patternmaking toolboxes, the following reflections tell us something of how the toolboxes came into being. Former patternmaker and current trade educator Anthony Freemantle started his apprenticeship in 1990 at the South African Railways company, before moving to Australia. He recalled,

That was one of my favorite parts. As a patternmaking apprenticeship it was part of our job to make a toolbox. Which was ... quite an exciting thing and I still have my toolbox sitting in my garage which I still use today. ${ }^{50}$

This is useful because it points to the pleasure Freemantle felt about this process, but also confirms that toolbox-production during an apprenticeship was by no means exclusive to Australia. ${ }^{51}$ Third generation Sydney patternmaker Peter Phipps - who still runs a patternmaking business today - recalled: "That's one of the first things that you did ... My father did that, my grandfather did that. Everyone did that." ${ }^{, 52}$ Peter's father, the aforementioned Bruce Phipps, undertook his patternmaking apprenticeship in the late 1940s on the Sydney shipbuilding site Cockatoo Island. Bruce similarly recollected, eyes twinkling: I made my toolbox, to start with. It was allowed to be done at Cockatoo [Island]... that was a very big job, because it had ... mortise and tenon joints in it, all hand-done ... and it had all drawers in it with a door that came down ... that was all made out of Cedar, which was pretty expensive timber in those days, and that was one of the things that we made. I got two of them, actually ... because I had more tools, and I needed them. ${ }^{53}$

Patternmakers often told me that they had such an abundance of necessary tools that one toolbox was never enough. The time taken to make one's first toolbox seemed to vary, but it was also dependent on the lenience of the patternshop. For former patternmaker Jon-Michael Rubinich, who undertook his apprenticeship in the early 2000s at a Melbourne patternshop, said, the "boss let me work on it for an hour or so every afternoon". ${ }^{54}$ The fact that Rubinich made a toolbox at all is significant: it shows us that some patternmakers were still handmaking toolboxes at the beginning of the twenty-first century. We will return to this issue later on. 
Once packed with tools, the toolbox was extremely heavy, and not generally intended as a mobile unit. In a twentieth century patternmaking context, the toolbox most often remained at the patternmaker's workplace, on the floor, often underneath a patternmaker's bench [Fig. 3] or, if there was space, on top of it. Australian patternmaker John Looker spent some time working in England in the mid-1950s, and transported his toolbox by ship, from Melbourne to London. In his memoir, Looker described arriving at his London workplace:

\begin{abstract}
I started work at Singer Motors ... I needed to take my bench top toolbox (the one with the new straps) with me. Loaded with tools it was heavy, and it was an effort to carry it to the bus stop ... The problem started at the Coventry bus station, 'Pool Meadows'. It was a long was up Ford Street to the Singer Works, and it involved many rest stops. I finally got there ... I surprised myself by saying that I could not lug my toolbox any further and would need assistance. ${ }^{55}$
\end{abstract}

The leather straps on Looker's toolbox had broken during the voyage from Sydney to London, and he recalled having sought a London leathermaker to make heavy-duty replacement straps, in an effort to make this unwieldy object more transportable. ${ }^{56}$

Patternmaker Debra Schuckar, who undertook her apprenticeship in the 1980s at the Victorian State Electricity Commission, is one of a very small number of female patternmakers. This has accorded her with a sense of critical distance: where male patternmakers tend to see 'natural' craft identity, she sees the constructedness of craft masculinity. She said, "I've still got [my toolbox] today ... It's almost like a male version of a glory box. [laughs]" ${ }^{, 57}$ Here, Schuckar essentially shows an implied understanding that, as Shields notes, "learning to be a tradesman meant growing into a particular socio-cultural identity; into a gendered language of craft". ${ }^{58}$ [Fig. 4]

\title{
[Insert Figure 4 near here-Debra Schuckar's toolbox]
}

Significantly, Schuckar's interview consistently returned to the notion that making one's own toolbox was part of a process of skill accrual. While the value of 'learning by doing' is a well-established pedagogical concept, recent trades education in Australia has devoted less 
time to technical exposure in classrooms and workshops. ${ }^{59}$ It is therefore important to explore the long-term value of giving apprentices a particularly difficult manual task. The toolbox had to be strong enough to hold a patternmaker's extensive tool collection, and it was expected to last a lifetime. This was arguably a complex undertaking, a substantial expectation to be placed on inexperienced, teenage apprentices.

I asked the patternmakers about this challenge. New Zealand patternmaker Stephen Smith reflected on the difficulty of making his toolbox: "I think being the freedom to make it, made it feel like it wasn't so difficult." 60 [Fig. 2] Schuckar provides valuable insights here, showing how at times the apprentices were supported by the tradespeople around them:

\begin{abstract}
We used Sugar Pine, and the boss taught me how to machine it ... then we clamped up some pieces together in the big sash clamps - which I'd never seen before in my life - and glued those up and then you re-machine them. Then he taught me how to do dovetailing ... and you make one big solid box. Then once you've made the box you cut the box on the circular saw and cut the lid off ... it makes the lid exactly the same as the box. Then you make the surrounds on it, and then make all the drawers inside. That was the first thing you spend time making before you get all your tools. ${ }^{61}$ [Fig. 4]
\end{abstract}

The making process for the toolbox proved to be a revelation for some of the patternmaker apprentices: teaching them how to join timber without the need for nails or screws, and teaching them to plan and execute a complex task with precision and care.

Like Schuckar, for former patternmaker Serge Haidutschyk, the toolbox-making exercise was an educational one. Haidutschyk's interview provides a degree of consistency with the other interviewees, summarizing many of their experiences:

I made my own toolbox ... which I've still got at home now, and I've got all my patternmaking, carving tools in there now, and that toolbox was made by me in my first year of apprenticeship. It took me, like, it took me about two months to make, and I was doing it in between making patterns ... I made this beautiful toolbox which was about a meter long, half a meter wide, with a beautiful lid on it, and it had shelves and drawers in it. Every apprentice had to make their own toolbox. ${ }^{62}$

As an interviewee, Haidutschyk was energetic, arms waving wide. He was full of enthusiasm about his former work as a patternmaker at the Victorian Government's Newport Railway 
Workshops, and thrilled that someone was finally taking the time to ask him about it. As

Haidutschyk explained, toolbox task was undertaken by following specific instructions:

The toolbox what had to be made to a specific specification and dimension ... all the framing and all the drawers was made out of Queensland Maple ... and also White Beech and a few other timbers ... local timbers. Australian timbers. ${ }^{63}$

Not all patternmakers followed a shop's specifications, and some apprentices extended the toolbox project much further, exercising their own unique design and materials decisions.

Bruce Phipps reflected, "you could go to a lot of trouble, or not a lot of trouble". ${ }^{64}$

The aforementioned Poynton certainly went to a lot of trouble. His was the most elaborate toolbox I encountered, the one that was 'magically preserved' after the Ash Wednesday bushfires. Poynton's toolbox process extended well beyond an apprentice-training exercise, and Poynton is quoted at length here, to do justice to the intricacy of his craft labor:

I made it during the course of my apprenticeship, probably took a period of about three years ... it's made from Queensland Maple, which we sometimes used in patterns. And unlike patternmaking where you're looking for really nice straight grained timber, you don't want any character in the timber as such. I've specially chosen what we call figured timber. ... So it's all carefully joined with sliding dovetail panels so they all lock together. There's no nails or screws holding the box together, only in the hinges. The lid, which hinges up from the back, there's a piano hinge on the back, once the lid is released there are two pins that go through the front panel on top of the box, on the front, and they're spring-loaded. And by shutting the lid, they're forced down into the top of the panel. And they locate in little brass inlays in the edge of the panel ... So once you open the lid, it exposes all the drawers ... all with really nicely figured timber, and all dovetail joins in the corners. So it's quite a thing, it's a lovely thing to still be able to have after the traumas of bushfire, it was magically preserved. ${ }^{65}$ [Fig 1]

Making a delicate toolbox with figured timber provided a much-needed creative outlet for Poynton as an apprentice, whose creative instincts were never entirely answered by the strict dimensional accuracy of patternmaking.

\section{Making Hand Tools}

Having made their toolbox, patternmaking apprentices then had to fill it. Patternmakers trained in the mid-twentieth century spoke of the challenge and expense of acquiring patternmaking tools, which included both woodworking and engineering instruments. 
Materials were scarce, and imported goods were expensive. ${ }^{66}$ A patternmakers' basic toolkit included a sharpening stone, various chisels, planes, gouges, measurement tools such as vernier calipers, metal shrinkage gauges, dividers and radiuses. It also included mallets, spoke shaves, clamps, knives, hammers, saws, files and hand-sanders, among other items. Australian apprentices received a paltry government-funded 'tool allowance' as part of their pay. As Peter Phipps recalled of his boss, "he'd always check on me that I was spending that tool allowance. ${ }^{67}$ Former patternmaker and high school teacher, Peter Williams, who undertook his apprenticeship at a private patternshop in Melbourne, said:

There were no rules about where they came from, but sooner or later you had to get your own [tools]. From Day 1 it was acceptable to borrow the Foreman's tools ... there was a component of tool allowance in there ... but, you know, the wages were pretty low as they were. So you collected tools any way you could. ${ }^{68}$

'Collecting' tools included being the lucky inheritor of a family member's tools, or obtaining a secondhand set from a retiring patternmaker. Williams was fortunate in this way. His father was a luthier, who also had connections with patternmakers.

Other apprentices were perhaps not as well connected, but found ways to make tools at their workplace. It helped if the workplace also had a foundry attached, so you could cast your own. On the making of hand tools, Poynton said:

Patternmakers require some unusual tools and not ones commercially available. So I was ever making tools even when I was sorta in the later stages of my apprenticeship. They used to call me Homer, because I was making so-called homers, or foreigners, and I'd spend at least an hour of my day somehow contriving to make part of a tool that I was working on or finishing. ${ }^{69}$

He later elaborated, "I made sometimes little wooden patterns for tools". These patterns could be taken to the adjacent foundry, and with a bit of cheek, he added, "we could talk the foundry into making these castings for little spoke shaves, and little planes and things". ${ }^{70}$

This final comment accords with existing studies of foreigner production, which established how the making of foreigners was often a reciprocal, cooperative activity involving more 
than one trade. ${ }^{71}$ Bruce Phipps described his understanding of the conditions for making foreigners: "when you were a bit slack, you were allowed to do it then. You had to get permission. 'Can I make this?’,72 By contrast, Poynton preferred a wilier strategy:

There was a wood store at the back and ... I used to go down, looking all official with my contraction rule and a rolled up drawing, out to the timber yard - and a handsaw - and I'd haul all the maple boards out of the rack and I'd cut off all the fiddle-back places and I'd take those ... just enough to fit in my bag, which is highly illegal really. ${ }^{73}$

There appears to have been a widespread social understanding that foreigner-making was " $\mathrm{a}$ good way for apprentices to practice new skills". ${ }^{74}$ Metal hand tools, such as chisels, could sometimes be bought without handles, and apprentices learned to handmake wooden handles to fit their personal preferences. As with toolbox-making, several patternmakers again emphasized the educational aspects of making one's own tools; it involved both metalwork and woodwork. Schuckar said:

We made a lot of tools ... learned how to tap, and learn how to use a metal lathe. ... lots of little calipers and things like that ... little clamps ... everything was made on the lathe from nothing out of bits of steel ... a gauge slot, a panel gauge, we made. They taught us how to make that. ${ }^{75}$

Reflecting more generally on the production of foreigners in the workplace, the patternmaker Tim Wighton also recalled the training potential of learning by doing, on site at work:

I got a lot of free rein to make foreigners, you know, things that I want to make ... And it wasn't frowned upon, as you weren't spending all day on it, as long as you were using scraps, and you were doing a bit here and there, it was okay ... as an apprentice as that was okay because you were learning so through doing, you're learning how to use the wood machinery and you're learning how to carve, learning all those techniques. ${ }^{76}$

Wighton's testimony is significant because it refers to a relatively recent apprenticeship experience - between 2005 and 2008. Even in the twenty-first century, foreigner production was, to some extent, tolerated in the patternshop. We will return to Wighton's experience in the following section, as there is one element that makes his recent experience quite different from the older patternmakers. 
Handmade patternmaking tools were a product of the patternmakers' need to produce work to precise dimensions, and bespoke measurement tools were often created as a solution to a specific problem in pattern planning. Gauges and radiuses were regularly mentioned, in addition to other tools that seemingly had no official name. Peter Phipps explained:

Some things you used to measure, like depth ...we'd make like these long fingers out of plywood ... I guess we'd call them 'long fingers' $\ldots$ you would make those tools specifically for those jobs. ${ }^{77}$

Similarly, when I visited Haidutschyk, he directed me to inspect a bench in his workshop, which was covered with carefully laid out handmade tools. Haidutschyk said:

As my apprenticeship was heading towards the fourth year, I also made a lot of tools that were specifically made for those jobs, like there was special radius gauges. There was a flat long router, special router ... There was miter clamps, there was a special carved hand plane for different diameters. There was a ... little center-finding tool ... I made about ten tools ... which you couldn't buy. ${ }^{78}$

In preparation for our interview, Haidutschyk had carefully labelled each item, and explained the specific use of each tool in painstaking detail. His pride in creating these objects was clearly apparent, and again reminds us that patternmakers craft much more than patterns. Ingenuity and resourcefulness seem to operate hand-in-hand with the patternmaking trade: it is almost as if, once you learned how to manipulate timber and metal, a whole world of making possibilities opened up.

It is important to reiterate that these individual and collective activities operated in a way that was to some extent outside of the control of business owners and management. While supervisors may be 'in on it', there was nothing official about these practices. They operated outside of a system of productivity and profit. Rather, they existed in something of a workers' commons: the moral economy of craft labor. ${ }^{79}$ The making of hand tools fed into a system which required craftspeople to own their own tools, which, for employee-patternmakers, gave them a degree of independence. However, as emphatically pointed out by an anonymous 
socialist patternmaker in 1904, tool ownership for a patternmaker was not quite the same as owning their means of production.

He would point with pride to his miserable collection of puny hand tools huddled together in his tool chest, and tell you that they were his own - they belonged to him - and that if he was dissatisfied with any particular employer he could lift his tools and seek another master. Quite true, oh wage slave! ... Unfortunately for him, capitalism could not stand still, but had to go on developing. ${ }^{80}$

While this patternmaker certainly makes some accurate predictions about the future precarity if the patternmaker, vis a vis capitalist development, he leaves out one key factor. Tool ownership gave patternmakers the freedom to themselves become capitalists - to set up their own businesses with relative ease (resulting in a proliferation of small patternmaking businesses). Patternmaking, however, was always at the mercy of other manufacturing industries, and could not stand on its own without foundries or plastics manufacturing to demand patterns.

\section{The Decline of the Handmade Apprentice Toolbox}

With recent public funding cuts to Australia's trades education system (TAFE), ${ }^{81}$ the formal education of patternmakers has suffered in a number of ways. Freemantle - who now teaches patternmaking to some of the few remaining apprentices - explained: "We insist still on teaching our students those traditional skills ... [but] they keep on reducing the [teaching] hours. We don't actually get them to make a toolbox anymore." 82 This has left the toolbox project solely to the whim of the apprentice's employer. Patternmaker and business owner Paul Kay previously employed and trained apprentices:

We all made our own toolboxes. I know in recent times I used to give my first-year apprentices a week, a solid week, to make their toolboxes, and you know, just get fully into it, because I knew how long it was going to take them. ${ }^{83}$

These days, however, Kay does not hire apprentices, and he works alone. He concedes that nowadays there is not enough work to go around, and little interest from younger people. 
Without foreigners and toolbox making, an apprentice's experience could feel dull and hollow: in their first year, apprentices were (and still are) generally given menial tasks, such as sweeping and cleaning, and fetching lunch. ${ }^{84}$ Another factor in recent years is the increasing availability of affordable, mass-produced metal toolboxes - such as Rhino or JV boxes - and heavy-duty tool shoulder-bags. While Tolpin rightly notes that metal toolboxes tend to blunt tools, they have nonetheless become popular in recent years. ${ }^{85}$ But, as I will briefly explore below, the increasing proliferation of the metal toolbox is not only a consequence of personal preference, or offshored mass-manufacturing, it also has a specific relationship to business rationalization trends.

What has happened to this culture of making things on the side, for personal and educational purposes, in the efficiency-driven corporate managerial culture of 'lean manufacturing' and standardization on the factory floor? As argued by vocational training researcher Karen Reilly-Briggs, "The ghost of Taylor is still alive in the twenty-first century", where scientific management "continues to underpin much of contemporary management thinking" in manufacturing. ${ }^{86}$ Here we will consider the impact of a contemporary standardization concept in relation to the aforementioned patternmaker Wighton, whose apprenticeship experience is intriguing because of its contrasts. Now aged in his early thirties, Wighton was trained in traditional methods of patternmaking, at a time when CNC machines were increasing in uptake. While this education in manual patternmaking methods (wood carving / pattern process planning) is something Wighton values, it also had the effect of making him dissatisfied with how management intersects with automated processes. As we have seen, Wighton's apprenticeship featured some of the same kind of craft adventures with foreignermaking as, for example, Poynton's in the mid-1950s. Some key apprenticeship experiences, 
however, were missing. Here is why: during Wighton's apprenticeship, his employer (an Australian foundry) was in the midst of instituting the popular ' $5 \mathrm{~S}$ ' strategy on the shopfloor.

' $5 \mathrm{~S}$ ' is a Japanese philosophy and organizational method that earned international renown after its application to the Toyota production system. ${ }^{87} 5 \mathrm{~S}$ stands for seiri (organization), seiton (neatness), seiso (cleaning), seiketsu (standardization) and shitsuke (discipline). ${ }^{88}$ Since the mid-twentieth century the concept has been employed in a wide variety of business contexts globally, and more recently incorporated into understandings of 'lean manufacturing' ${ }^{89} 5 \mathrm{~S}$ is an attractive strategy for managers because it provides swift, visible results of active 'management' with little effort. The concept puts a high value on neatness, and requires - among other things - workers to 'clean up' their factory areas, removing all unnecessary items, standardizing furniture, machinery and benchtops, and changing the way that tools are stored and displayed. The application of this standardization principle has had a direct impact on the material culture of the shopfloor, and on industrial craft practices.

At the foundry where Wighton undertook his apprenticeship, 5S involved routinely cleaning the foundry and patternshop, installing shadow-boards for tool storage, among other standardization and safety strategies. One result of this institutionalized tidying was that the handmade toolbox was removed from the shopfloor. Wighton reflected:

Everything had to be standardized. Everybody had to have the same metal toolbox, which was way too small, to be honest. It was just a single toolchest that had about three drawers ... and the other three drawers or top. And you were expected to try and fit everything of yours in there, which was impossible..$^{90}$

The patternmakers' workbenches were also standardized, introducing small mobile steel benches, which most patternmakers also felt were inadequate. [Fig. 6] There was understandable resistance to this imposition of standardization, as it was impractical and separated patternmakers from an object that was core to their identity. But this was also a 
period of employment precarity: Australian manufacturing during the 2007 Global Financial Crisis was on shaky ground, and jobs were not plentiful. In this potentially insecure context, most patternmakers begrudgingly complied with the standardization measures, with the exception of a few stalwart, older-generation patternmakers. Wighton continued:

I think there was only two people in the 'shop that got away with actually keeping their original toolboxes, because they kicked up such a fuss that it wasn't worth trying to pry it out of their hands basically ... It's why I never got to make my patternmaker's toolbox. ${ }^{91}$

This is how I first learned of the significance of the patternmaker's toolbox: from a patternmaker who was never given the chance to make one during his apprenticeship.

[Insert Figure 6 near here - Wighton's bench + toolbox]

The arrival of workplace rationalization and technological change had relegated the patternmaking toolbox to the domestic workshop, even for the patternmakers still working in their trade. There, these boxes became lingering physical reminders of trade identity. At the time of writing (2019) Schuckar is still working in a Melbourne patternshop. Her original toolbox, however, now resides in her home workshop. Likewise, Peter Phipps said laughingly, "there's a couple of coffee tables in our house here that are old toolboxes."92 Peter and his father Bruce introduced CNC machines into their patternmaking business, which transformed their relationship to patternmaking tools. A consideration of the locations of these toolboxes highlights the material and cultural connections that exist between the home and the industrial workplace. Geographer Chantel Carr has explored how, in the context of deindustrializing communities, skilled labor practices 'spill out' of the workplace, reappearing in the domestic context through material culture, and in the form of maintenance and repair practices. ${ }^{93}$ This example demonstrates how some of this 'overspill' can occur as a result of a managerial drive for a particular idealised image of sleek factory uniformity.

\section{Conclusion}


With the increasing uptake of technologies such as CAD and CNC machines, hand tools and their toolboxes evidently receded in significance. Peter Phipps summed this up: "Yeah, the toolkit's short-changed these days because I'm so used to CAD work, and CNC now ... you've got a computer screen! (laughs)"94 Indeed, many contemporary patternmakers no longer carve timber to make patterns. Instead, their tasks are about CAD programming and machine set-up and finishing: digitally fabricating patterns out of timber or polyurethane, and hand-finishing them. But is it too soon to dismiss patternmakers' traditional woodcarving skills (and their requisite tools and toolboxes) as redundant? During one fieldwork trip in 2017, I was informed that a foundry patternshop's CNC machine was broken. I asked whether the patternmakers went back to handmaking patterns when the CNC machine was out of action. The answer was no, as one patternmaker explained,

A lot of the designers on site are so used to everything being made on CNC ... that they don't consider anyone in the shop capable to make patterns by hand any more. ${ }^{95}$

There is evidently a great deal that could be said, in perhaps another forum, about the inefficiency and waste of human skill that this sort of situation represents. But it is specifically shared here to indicate how apparently innocuous managerial strategies such as 5S have tangible and intangible effects. Not only do they transform spaces, they also transform the way in which managers and business owners regard industrial craftspeople. Such managerial strategies can function as a form of institutionalized collective amnesia, with concrete results for the workers who are subject to such systems.

This article has drawn upon oral histories in order to highlight how toolboxes and hand tools were crafted 'on the side' in the industrial workplace, in a tacitly accepted form of industrial craft enculturation and skills development. The broader intention of my research is to draw attention to the significance of industrial craft - both its history and its contemporary manifestations - arguing for the increasing recognition of industrial craft and trade skills in 
academic studies of design and craft (and more broadly in the public arena). My choice in emphasizing toolbox production here is a conscious attempt to demonstrate the cultural and pedagogical value of seemingly 'unproductive' practices at work. To this end, I hope to encourage positive attention towards a broader spectrum of 'non-economic' exercises of craft stewardship. Craft practices such as foreigner-making are undertaken as a form of stewardship and care; ${ }^{96}$ they are about developing resilience, materials knowledge, problemsolving ability and manual skill. These capacities may be sorely needed in the future, in an increasingly resource-constrained and degraded environment in need of infrastructural maintenance and repair. The making of foreigners - whether they be semi-official or entirely under the radar - represents a set of practices that value making and fixing over consuming, that value knowledge-sharing over corporate control, sustainably maintaining culture, resources and place.

\section{Notes}

${ }^{1}$ Bryan Poynton, interview with author, Reshaping Australian Manufacturing Oral History Project (Canberra: National Library of Australia, February 22, 2018), https://nla.gov.au/nla.cat-vn7580610.

${ }^{2}$ Serge Haidutschyk, interview with author, Reshaping Australian Manufacturing (Canberra: NLA, December 4, 2018), https://nla.gov.au/nla.cat-vn7889878.

${ }^{3}$ See also Marilyn Zapf, The Making of Industrial Artisans: Training Engineers in Britain, 1964-1979, Masters Dissertation, RCA, V\&A History of Design, London, 2012, pp. 82-8. ${ }^{4}$ I have chosen to use the present tense here, as patternmaking is an ongoing practice. See: Larissa Romensky, "Hard, Dirty Foundry Work Copes with Digital Disruption”, $A B C$ News (September 30, 2018), www.abc.net.au/news/2018-09-30/hard-dirty-foundry-work-coping- 
with-digital-disruption/10303254; Jesse Adams Stein, "Don't be too quick to dismiss 'dying trades', those skills are still in demand", The Conversation (December 6, 2018), https://theconversation.com/dont-be-too-quick-to-dismiss-dying-trades-those-skills-are-stillin-demand-107894.

${ }^{5}$ Glenn Adamson, The Invention of Craft (London \& New York: Bloomsbury, 2013), p. 145. ${ }^{6}$ Sarah Fayen Scarlett, “The Craft of Industrial Patternmaking”, Journal of Modern Craft 4(1) (2011), pp. 27-48.

${ }^{7}$ Ibid., p. 30.

${ }^{8}$ David F. Noble, "Social Choice in Machine Design: The Case of Automatically Controlled Machine Tools", in Andrew Zimbalist (ed.), Case Studies on the Labor Process (New York: Monthly Review Press, 1979), pp. 18-50. Noble's position follows Harry Braverman, Labor \& Monopoly Capital (New York \& London: Monthly Review Press, 1974). See also John Charles Wren, Skilled Trades' Work and Apprentice Training in the Manufacturing Industry with a Primary Focus on the Millwright Trade, $\mathrm{PhD}$ thesis (Toronto: University of Toronto, 2008), pp. 60-1.

${ }^{9}$ Brian Knight, Evolution of Apprenticeships and Traineeships in Australia: An Unfinished History (Adelaide: National Centre for Vocational Education Research [NCVER], 2012). ${ }^{10}$ Merle Patchett, "Historical Geographies of Apprenticeship: Rethinking and Retracing Craft Conveyance over Time and Place,” Journal of Historical Geography 55 (2017), p. 31.

${ }^{11}$ John Shields, "Craftsmen in the Making: The Memory and Meaning of Apprenticeship in Sydney between the Great War and the Great Depression", in Shields (ed.), All our Labours: Oral Histories of Working Life in Twentieth Century Sydney (Sydney: University of New South Wales Press, 1992), p. 95.

${ }^{12}$ At the time of writing (2019), there are only seven engineering patternmaking apprentices currently training in Australia. 
${ }^{13}$ University of Technology Sydney (UTS) Ethics \#ETH16-1004. Participants from this interview set are anonymized.

${ }^{14}$ Reshaping Australian Manufacturing Oral History Project, National Library of Australia (NLA), 2017-2019, https://nla.gov.au/nla.cat-vn7540760. UTS Ethics \#ETH17-1385.

${ }^{15}$ For thorough research into industrial craft training manuals, see Marilyn Zapf, The Making of Industrial Artisans: Training Engineers in Britain, 1964-1979, MA Dissertation (London: RCA, 2012).

${ }^{16}$ Arlene Oak, "Particularising the Past: Persuasion and Value in Oral history Interviews and Design Critiques”, Journal of Design History 19(4) (2006), pp. 345-56.

${ }^{17}$ Ezra Shales, “A 'Little Journey' to Empathize with (and Complicate) the Factory”, Design and Culture 4(2) (2012), p. 218.

${ }^{18}$ See also Alistair Thomson, "Life Histories and Historical Analysis", in Simon Gunn \& Lucy Faire (eds.), Research Methods for History, 2nd ed (Edinburgh: Edinburgh University Press, 2016), pp. 104-21.

${ }^{19}$ Stephen Knott, Amateur Craft: History and Theory (London: Bloomsbury, 2015), pp. 612; Jim Tolpin, The Toolbox Book (Newtown CT: The Taunton Press, 1995).

${ }^{20}$ See for example from this journal: Jon Wood, “Tools of Trades," The Journal of Modern Craft 3(3) (2010), pp. 277-8; Celine Johnson Soliz, "Clay, Tools and Tooling," The Journal of Modern Craft 3(3) (2010), pp. 349-54; Ethan W. Lasser, "Factory Craft: Art and Industry in Conversation," Journal of Modern Craft 6(3) (2013), pp. 315-20. See also industrial craft tools discussed in Thomas L. Steiger, "Construction Skill and Skill Construction”, Work, Employment \& Society 7(4) (1993), pp. 535-60.

${ }^{21}$ To be more precise: Patternmakers also produced extra toolboxes throughout their careers, so toolboxes were not exclusively made in the first year apprenticeship stage. 
22 Janis Wilton, “Telling Objects: Material Culture and Memory in Oral History Interviews", Oral History Association of Australia Journal 30 (2008), pp. 41-9.

${ }^{23}$ Michel Anteby, “Factory 'Homers': Understanding a Highly Elusive, Marginal, and Illegal Practice”, Sociologie du Travail 48 (2006), pp. 233-8.

${ }^{24}$ Meaning 'the wig'. Michel De Certeau, The Practice of Everyday Life, trans. Steven Rendall (Berkeley \& London: University of California Press, 1984), pp. 24-8.

${ }^{25}$ Anteby, “The 'Moralities' of Poaching: Manufacturing Personal Artifacts on the Factory Floor', Ethnography 4 (2003), p. 219; Graham Seal, "Foreigners in Workplace Culture", in Jennifer Harris (ed.), Foreigners: Secret Artefacts of Industrialism (Perth: Black Swan Press, 2009), p. 38.

${ }^{26}$ Anteby, "The 'Moralities' of Poaching; Anteby, "Factory 'Homers"”, Anteby, Moral Gray Zones: Side Productions, Identity, and Regulation in an Aeronautic Plant (Princeton:

Princeton University Press, 2008).

${ }^{27}$ Key studies of the practice in the Australian context include: Bertola and Oliver (eds), The Workshops; Harris (ed.), Foreigners; Jesse Adams Stein, Hot Metal: Material Culture \& Tangible Labour (Manchester University Press, 2016).

${ }^{28}$ In addition to the previously cited examples, see also: Miklos Haraszti, $A$ Worker in a Worker's State (New York, Universe Books, 1978); Robert Kosmann, “La Perruque ou le Travail Masqué”, Histoire 11 (1999), pp. 20-7.

${ }^{29}$ Bobbie Oliver, "Making Foreigners at the Midland Government Railway Workshops, 1904-1994", in Harris (ed), Foreigners, p. 26.

${ }^{30}$ Ibid., p. 35 .

${ }^{31}$ Stephen Smith, "Foreigners: 'The Forbidden Artefact'”, in Foreigners, pp. 21-3.

${ }^{32}$ Jason Ditton, "Perks, Pilferage and the Fiddle: The Historical Structure of Invisible Wages", Theory and Society 4(1) (1977), pp. 39-71. 
${ }^{33}$ E.P. Thompson, "Patrician Society, Plebian Culture", Journal of Social History 7(4) (1974), p. 384.

${ }^{34}$ Ditton, "Perks, Pilferage and the Fiddle", p. 49.

${ }^{35}$ Adrian J. Randall, "Peculiar Perquisites and Pernicious Practices: Embezzlement in the West of England Woollen Industry, c. 1750-1840”, International Review of Social History 35 (1990), pp. 193-219.

${ }^{36}$ Anteby, "Factory 'Homers", p. e23.

${ }^{37}$ See Ibid., also Patrick Bertola and Bobbie Oliver (eds), The Workshops: A History of the Midland Government Railway Workshops (Perth: University of Western Australia Press, 2006); Harris (ed), Foreigners.

${ }^{38}$ Oliver, "Making Foreigners", p. 36.

${ }^{39}$ Ibid.

${ }^{40}$ McCracken, "The Workforce Cultures", in The Workshops, pp. 209-10.

${ }^{41}$ Smith, "Foreigners", p. 22.

${ }^{42}$ The rules of the Midland Government Railway Workshops, Western Australia, cited by Ric McCracken, "The Workforce Cultures”, pp. 209-10.

${ }^{43}$ Oliver, "Making Foreigners", p. 33.

${ }^{44}$ Poynton, interview with author; Bruce Phipps, interview with author, Reshaping Australian Manufacturing (Canberra: NLA, May 31, 2018), https://nla.gov.au/nla.cat-vn7765732.

${ }^{45}$ Tolpin, The Toolbox Book, pp. 36-7.

${ }^{46}$ Ibid, p. 10.

${ }^{47}$ Zapf, The Making of Industrial Artisans, p. 85.

${ }^{48}$ Ibid., pp. 82-8.

${ }^{49}$ Ibid., p. 87.

${ }^{50}$ Freemantle, interview with author. 
${ }^{51}$ Anecdotal evidence from interviews and social media analysis suggests patternmakers in the United Kingdom and New Zealand also made toolboxes during their apprenticeship.

${ }^{52}$ Peter Phipps, interview with author, Reshaping Australian Manufacturing (Canberra: NLA, May 11, 2018), https://nla.gov.au/nla.cat-vn7765727.

${ }^{53}$ Bruce Phipps, interview with author.

${ }^{54}$ Jon Michael Rubinich, Patternmakers’ Facebook Group, 29 January 2018, www.facebook.com/groups/502920693172756.

${ }^{55}$ John Looker, I Want to be a Patternmaker: A Memoir (Melbourne: Memoirs Foundation Publishers, 2011), pp. 84-5.

${ }^{56}$ Ibid., p. 83.

${ }^{57}$ Debra Schuckar, interview with author, Reshaping Australian Manufacturing (Canberra:

NLA, February 23, 20180, https://nla.gov.au/nla.cat-vn7580622.

${ }^{58}$ Shields, "Craftsmen in the Making”, p. 106.

${ }^{59}$ Karen Reilly-Briggs, National Training Reform and the Impact on Vocational Education for Metal Engineering Trades in Victoria, $\mathrm{PhD}$ thesis (Melbourne: La Trobe University, 2016), p. 39.

${ }^{60}$ Stephen Smith, personal communication with author, 27 February 2019.

${ }^{61}$ Schuckar, interview with author.

${ }^{62}$ Haidutschyk, interview with author.

${ }^{63}$ Ibid.

${ }^{64}$ Bruce Phipps, interview with author.

${ }^{65}$ Poynton, interview with author.

${ }^{66}$ Looker, I Want to be a Patternmaker, p. 38.

${ }^{67}$ Peter Phipps, interview with author. 
${ }^{68}$ Peter Williams, interview with author, Reshaping Australian Manufacturing (Canberra:

NLA, 26 November 2017), https://nla.gov.au/nla.cat-vn7540153.

${ }^{69}$ Poynton, interview with author.

${ }^{70}$ Ibid.

${ }^{71}$ Smith, "Foreigners".

${ }^{72}$ Bruce Phipps, interview with author.

${ }^{73}$ Poynton, interview with author.

${ }^{74}$ Kathy Bell, “The Midland Junction Railway Workshops, 1920-1939”, in J. Gregory (ed.), Studies in Western Australian History XI (Nedlands: UWA Press, 1990), p. 33. Also cited in Oliver, "Making Foreigners", p. 29.

${ }^{75}$ Schuckar, interview with author.

${ }^{76}$ Tim Wighton, interview with author, Reshaping Australian Manufacturing (Canberra:

NLA, November 27, 2017), https://nla.gov.au/nla.cat-vn7540155.

${ }^{77}$ Peter Phipps, interview with author.

${ }^{78}$ Haitudschyk, interview with author.

${ }^{79}$ Seal, "Foreigners in Workplace Culture," p. 46.

${ }^{80}$ Unknown Patternmaker, "Pattern Making and Capitalism", The Socialist (November 1904), p. 7.

${ }^{81}$ Reilly-Briggs, National Training Reform.

${ }^{82}$ Freemantle, interview with author.

${ }^{83}$ Paul Kay, interview with author, Reshaping Australian Manufacturing, (Canberra: NLA, April 30, 2018), https://nla.gov.au/nla.cat-vn7765725.

${ }^{84}$ Shields, "Craftsmen in the Making", p. 100.

${ }^{85}$ Tolpin, The Toolbox Book, p. 3.

${ }^{86}$ Reilly-Briggs, National Training Reform. 
${ }^{87}$ Kaoru Kobayashi, Ron Fisher \& Rod Gapp, “Business Improvement Strategy or Useful Tool? Analysis of the Application of the 5S Concept in Japan, the UK and the US", Total Quality Management and Business Excellence 19(3) (2008), pp. 245-62.

${ }^{88}$ Ibid., p. 245. English translations vary slightly.

${ }^{89}$ Steven Imp, “Leak Test Process: Using Lean and 5S to Drive Manufacturing Process Improvements", Quality (September 2011), pp. 30-4.

${ }^{90}$ Wighton, interview with author.

${ }^{91}$ Wighton, personal communication with author.

${ }^{92}$ Peter Phipps, interview with author.

${ }^{93}$ Chantel Carr, "Maintenance and Repair Beyond the Perimeter of the Plant: Linking Industrial Labour and the Home", Transactions of the Institute of British Geographers 42(4) (2017), pp. 642-54.

${ }^{94}$ Peter Phipps, interview with author.

${ }^{95}$ Anonymous respondent from 2015 foundry fieldwork.

${ }^{96}$ Frances Flanagan, “Climate Change and the New Work Order”, Inside Story (February 28, 2019), https://insidestory.org.au/climate-change-and-the-new-workorder/?fbclid=IwAR1bNMOxdZGwOTCUdhsp6F2K9mgdIZsZfiLEGCC2YEEZEX3xX4JWKceQX0. 